Article

\title{
Evaluation of Hygrothermal Behaviour in Heritage Buildings through Sensors, CFD Modelling and IRT
}

\author{
Carlos Lerma ${ }^{1, * \mathbb{C}}$, Júlia G. Borràs ${ }^{1}$, Ángeles Mas ${ }^{1}$, M. Eugenia Torner ${ }^{2}$, Jose Vercher ${ }^{1} \mathbb{C}$ and Enrique Gil ${ }^{2}$ \\ 1 Department of Architectural Constructions, Universitat Politècnica de València, Camino de Vera $\mathrm{s} / \mathrm{n}$, \\ 46022 Valencia, Spain; jugarbor@csa.upv.es (J.G.B.); amas@csa.upv.es (Á.M.); jvercher@csa.upv.es (J.V.) \\ 2 Department of Continuous Medium Mechanics and Theory of Structures, Universitat Politècnica de València, \\ Camino de Vera s/n, 46022 Valencia, Spain; meutorfe@upvnet.upv.es (M.E.T.); egil@upv.es (E.G.) \\ * Correspondence: clerma@csa.upv.es
}

check for updates

Citation: Lerma, C.; Borràs, J.G.; Mas, Á.; Torner, M.E.; Vercher, J.; Gil, E. Evaluation of Hygrothermal Behaviour in Heritage Buildings through Sensors, CFD Modelling and IRT. Sensors 2021, 21, 566. https:// doi.org/10.3390/s21020566

Received: 25 November 2020 Accepted: 11 January 2021 Published: 14 January 2021

Publisher's Note: MDPI stays neutral with regard to jurisdictional clai$\mathrm{ms}$ in published maps and institutional affiliations.

Copyright: (C) 2021 by the authors. Licensee MDPI, Basel, Switzerland. This article is an open access article distributed under the terms and conditions of the Creative Commons Attribution (CC BY) license (https:// creativecommons.org/licenses/by/ $4.0 /)$.

\begin{abstract}
Architectural heritage, building materials and interior space are highly susceptible to temperature and relative humidity. A better knowledge of the hygrothermal dynamics inside buildings allows an adequate conservation of heritage. This work compares three non-destructive techniques (NDT), such as temperature and relative humidity sensors, finite element simulations (CFD) and thermographic pictures (IRT). The work has made it possible to carry out an assessment of the risk of condensation over a year and to identify affected periods and areas of the building. Sensors and IRT pictures provide real data to validate CFD simulations, facilitating a global analysis of the building. The results provided reflect a great concordance between the NDTs used.
\end{abstract}

Keywords: CFD; IRT; natural convection; building materials; heritage

\section{Introduction}

Heritage conservation focuses its efforts on the early detection of pathology. Knowing climatic parameters inside buildings and the response of construction materials helps to have a better understanding of reality. The development of non-destructive tests (NDT) are widely used [1-6], since they provide information on real cases and allow analysis and diagnosis [7], as well as a monitoring tool of the work's progress and the assessment of materials and rehabilitation interventions [8]. The goal is preventive conservation while minimizing damage $[9,10]$. In this sense, various types of sensors or instruments have been used to monitor this type of building [11-16].

In buildings with natural ventilation, the air movement only depends on wind speed and indoor-outdoor temperature gradient [17]. High relative humidity and low temperatures are conditions that commonly occur in heritage buildings such as churches [18]. The study of the conditions inside the churches has been analysed to know the behaviour as a function of the external conditions and the construction materials [19]. A multidisciplinary approach on historic building microclimate facilitates the identification of the main causes of deterioration in the heritage and allows to suggest conservation strategies [20]. Also, monitoring and analysing microclimate with the environmental conditions would be suitable for preservation of historical buildings as a result of thermodynamic simulation [21]. On the one hand, variations in temperature and relative humidity damage construction materials $[22,23]$. On the other hand, the ventilation rate due to user behaviour, window-opening habits and others must also be considered [24].

It is a great novelty to use a finite element software for modelling using Computational Fluid Dynamics (CFD) by applying it to the inside of a building to study the hygrothermal behaviour. Thermal calculations have already been made with finite elements in specific parts of buildings, such as in the encounter between enclosures, slabs and cantilevers [25]. Simulations were performed with the software Ansys Fluent 2020 R2. The parameters and 
characteristics of the simulations were carried out in accordance with the software application manual [26]. This program has been widely used in other branches of engineering, for the simulation of vehicle behaviour (Formula 1 cars, airplanes...), but also for buildings and heritage [27,28], as well as ventilation in buildings [29-31].

However, CFD and sensors, together with Infrared Thermography (IRT), have not been used in combination so far. Non-destructive techniques, such as IRT, facilitate the study of materials and allow understanding and deepening the understanding of materials and construction processes, without the need to cause damage to the building. IRT has been widely used for the protection of heritage [32] and information about the materials is provided, as well as the factors, processes and state of deterioration, and the detection of defects [33,34]. A combination of simplified and advanced analytical methods allows to perform predictive analysis of behaviour [35,36], along with the monitoring of building materials and identification of their pathology $[37,38]$.

This study combines three non-destructive techniques (sensors, CFD and IRT) and compares the results obtained. The proposed methodology seeks to determine those areas of the buildings that are susceptible to deterioration of the materials. The risk of condensation, which depends on certain conditions of relative temperature and humidity, is evaluated. The real data from the sensors and from the thermographic pictures allow to validate the simulations carried out with the CFD model of the building.

\section{Materials and Methods}

The objective pursued in this research is to demonstrate the correlation between real data and computer simulations in order to validate the latter. The scope of study has focused on the analysis of temperature and humidity inside a heritage building. The real data of temperature and relative humidity have been provided by sensors distributed throughout the building. Infrared thermography has been used to complete this analysis with real temperature data.

The real data can be compared with those obtained by simulations and, where appropriate, validated. The simulations cover the entire volume of the building, so their subsequent study allows to obtain a better understanding of the hygrothermal dynamics. Thus, it is possible to identify critical situations or areas susceptible to condensation and, therefore, deterioration of construction materials.

\subsection{Case Study}

To carry out this research, a four-century-old heritage building was chosen, one of the most important Baroque temples among the architectural examples of this period in Spain [39-42]. It is a representative example of the medieval churches of the 17th century in Valencia (Spain) and a good part of the European territory $[43,44]$. It is the Church of La Asunción de Llíria, built between 1626 and 1783 [45]. These buildings have thick façade walls, a large volume of air inside and few ventilation and lighting holes. In addition, they have a very specific (religious) use concentrating a significant number of people at very specific times (masses).

The location of the building is unique since it is partially excavated in the mountain and has annex buildings (Figure 1). The building consists of a central nave, two sides with chapels between buttresses, an altar, a transept with a dome, as well as other rooms (offices, warehouses). 


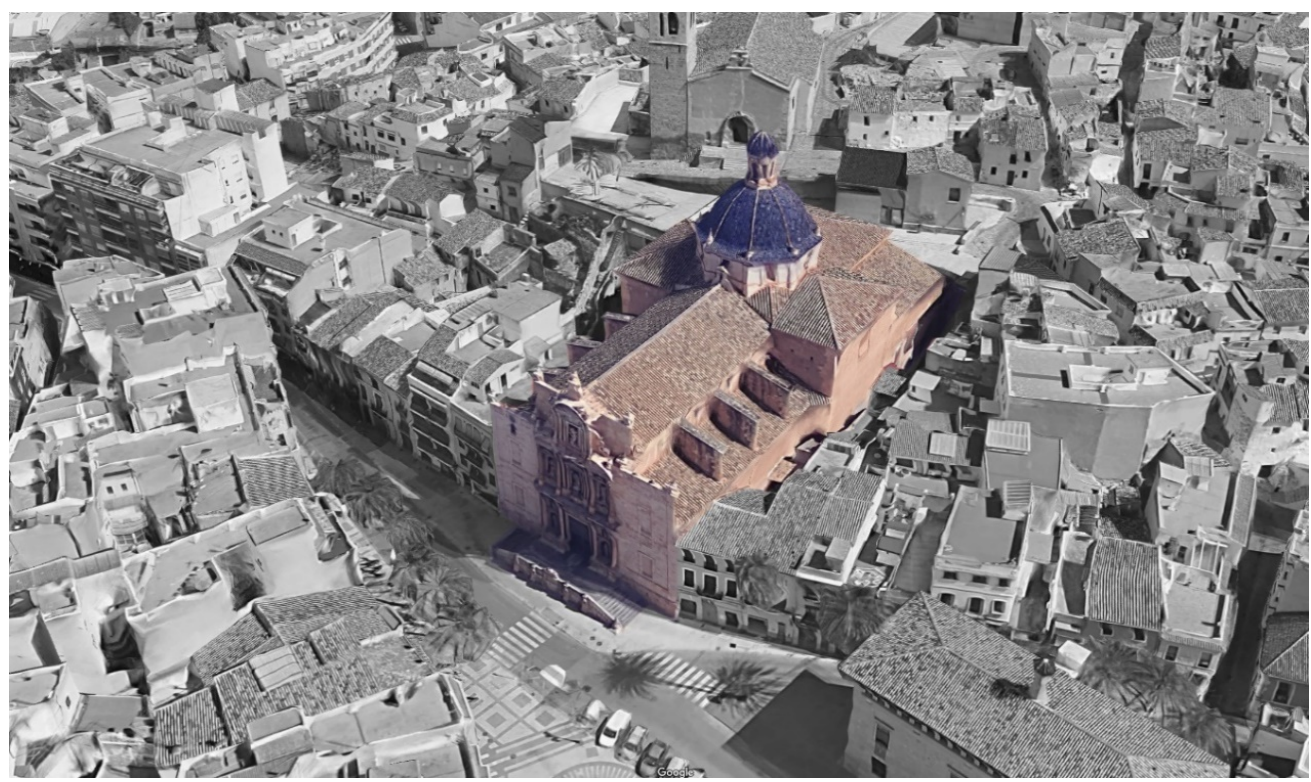

Figure 1. Aerial view of the building (Source: Google \& National Geographic Institute of Spain).

\subsection{Real Data with Sensors}

Temperature and relative humidity data have been recorded from August 2019 to August 2020. Data has been stored for 13 months so that the building's response can be observed in all seasons. Likewise, it has coincided with periods of confinement and mobility restrictions for people derived from the Sars-Cov-2 virus and the COVID-19 disease, leaving the building without any activity and without human presence for several weeks between March and June 2020.

For the acquisition of temperature and humidity data, six low-cost data loggers from Perfec-Prime [46] were used, whose main characteristics are shown in Table 1. The recommendations of the European standard EN 15758 about the conservation of cultural property, procedures and instruments for measuring temperatures of the air and surfaces of objects have been followed [47].

Table 1. Main characteristics of the data-loggers.

\begin{tabular}{cc}
\hline Feature & Value \\
\hline Temp. measurement range & $40{ }^{\circ} \mathrm{C}$ to $125^{\circ} \mathrm{C}$ \\
Humidity measurement range & 0 to $100 \% \mathrm{RH}$ \\
Max. capacity & 21,000 values \\
Temp. measurement accuracy & $\pm 0.3^{\circ} \mathrm{C} @ 25^{\circ} \mathrm{C}$ \\
Humidity measurement accuracy & $\pm 2 \% \mathrm{RH} @ 25^{\circ} \mathrm{C}$ \\
\hline
\end{tabular}

The sensors are autonomous (Battery: $3 \mathrm{~V}$, AAA) and the values have been recorded every $30 \mathrm{~min}$. Current sensors allow the recording of values between 1 day and $1 \mathrm{~min}$, but more frequently a large amount of information is generated, and it is necessary to store it [48]. Every $30 \mathrm{~min}$ it is possible to obtain the temperature wave along the day with great precision and with an excellent battery performance.

A total of 109,478 records have been reached. Each record includes the value of temperature, relative humidity, date, time, and sensor number. This assumes more than 200,000 values of temperature and relative humidity.

The location of the sensors is indicated in Table 2 and Figure 2. The sensors have been sought to be in different orientations of the building, as well as at different heights. 
Table 2. Location of the data-loggers in the building.

\begin{tabular}{ccccc}
\hline Sensor & Location & Orientation & $\begin{array}{c}\text { Coordinates } \\
\mathbf{( x ,}, \mathbf{y})\end{array}$ & Height $(\mathbf{m})$ \\
\hline S1 & Int & - & $31.25,7.13$ & +3.00 \\
S2 & Int & North & $28.82,25.33$ & +1.50 \\
S3 & Int & West & $2.41,6.28$ & +1.50 \\
S4 & Int & South-West & $2.41,3.22$ & +0.25 \\
S5 & Int & North & $13.55,23.98$ & +14.00 \\
S6 & Ext & East & $56.85,13.21$ & +15.50 \\
\hline
\end{tabular}

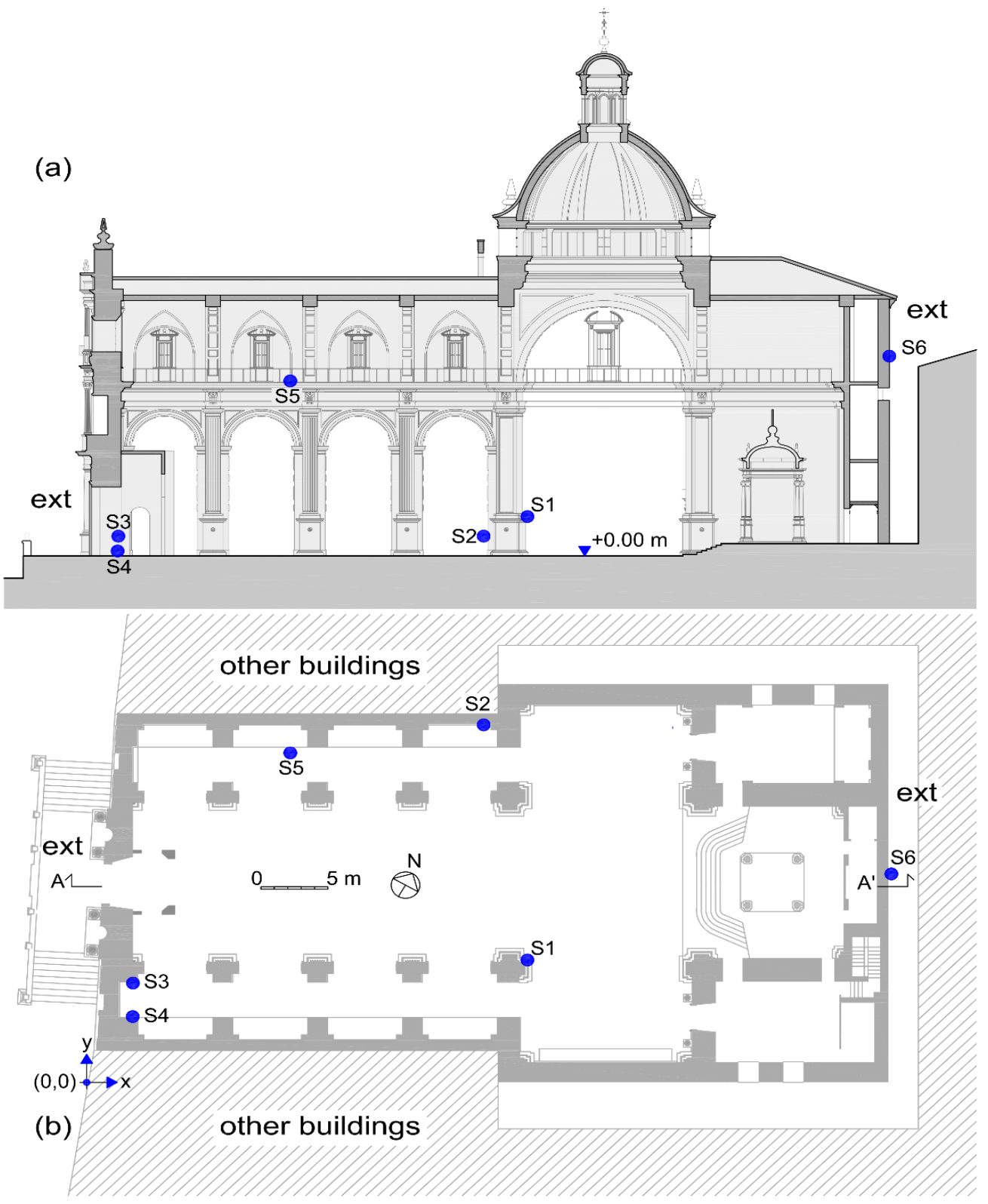

Figure 2. Sensors location in the building: (a) section $A-A^{\prime}$ and (b) plan view.

\subsection{Computational Fluid Dynamics (CFD) Simulation}

CFD simulations are done with the software Ansys Fluent. The model comprises, with a simplified geometry, the entire volume of air inside the building, considering the openings of doors and windows as air inlets and outlets, wall arrangements, pillars, dome, etc. 
In this research, the analysis has focused on the most extreme cases: summer and winter in order to make the contrasts more evident. The data used in the simulations as boundary conditions are shown in Table 3, taken from the sensors. The data for summer correspond to 9 August 2019 at 5:40 p.m. where the maximum outdoor temperature was reached and those for winter correspond to 20 January 2020 at 7:50 p.m. where the minimum outdoor temperature was reached.

Table 3. Real data from the sensors used for the simulations.

\begin{tabular}{lcccc}
\hline \multirow{2}{*}{ Sensor } & \multicolumn{2}{c}{ Winter } & \multicolumn{2}{c}{ Summer } \\
\cline { 2 - 5 } & Temperature $\left({ }^{\circ} \mathbf{C}\right)$ & RH (\%) & Temperature $\left({ }^{\circ} \mathbf{C}\right)$ & RH (\%) \\
\hline S1 $(3 \mathrm{~m})$ & 14.1 & 53.2 & 26.4 & 64.5 \\
S2 $(1.5 \mathrm{~m})$ & 14.3 & 52.3 & 25.3 & 68.5 \\
S3 $(1.5 \mathrm{~m})$ & 14.1 & 51.4 & 26.4 & 62.1 \\
S4 $(0.25 \mathrm{~m})$ & 14.1 & 52.1 & 26.4 & 63.9 \\
S5 $(14 \mathrm{~m})$ & 13.4 & 52.1 & 27.9 & 50.9 \\
S6 $(15.5 \mathrm{~m})$ EXT & 7.9 & 78.8 & 37.9 & 22.6 \\
\hline
\end{tabular}

The finite element mesh has been created automatically by the software since the global study of the building did not consider local regions that require special analysis. Although a maximum size of the element is indicated to guarantee a sufficient number of nodes and that the precision when performing the calculations is optimal. In this sense, the model consists of approximately 36,108 total nodes and 189,590 elements. The minimum mesh is $1 \times 1 \mathrm{~m}^{2}$ (Figure 3). The finite element model is a simplification of the real geometry of the building. Blue vectors indicate the velocity inlet flow and red vectors the velocity outlet one with CFD setup parameters.

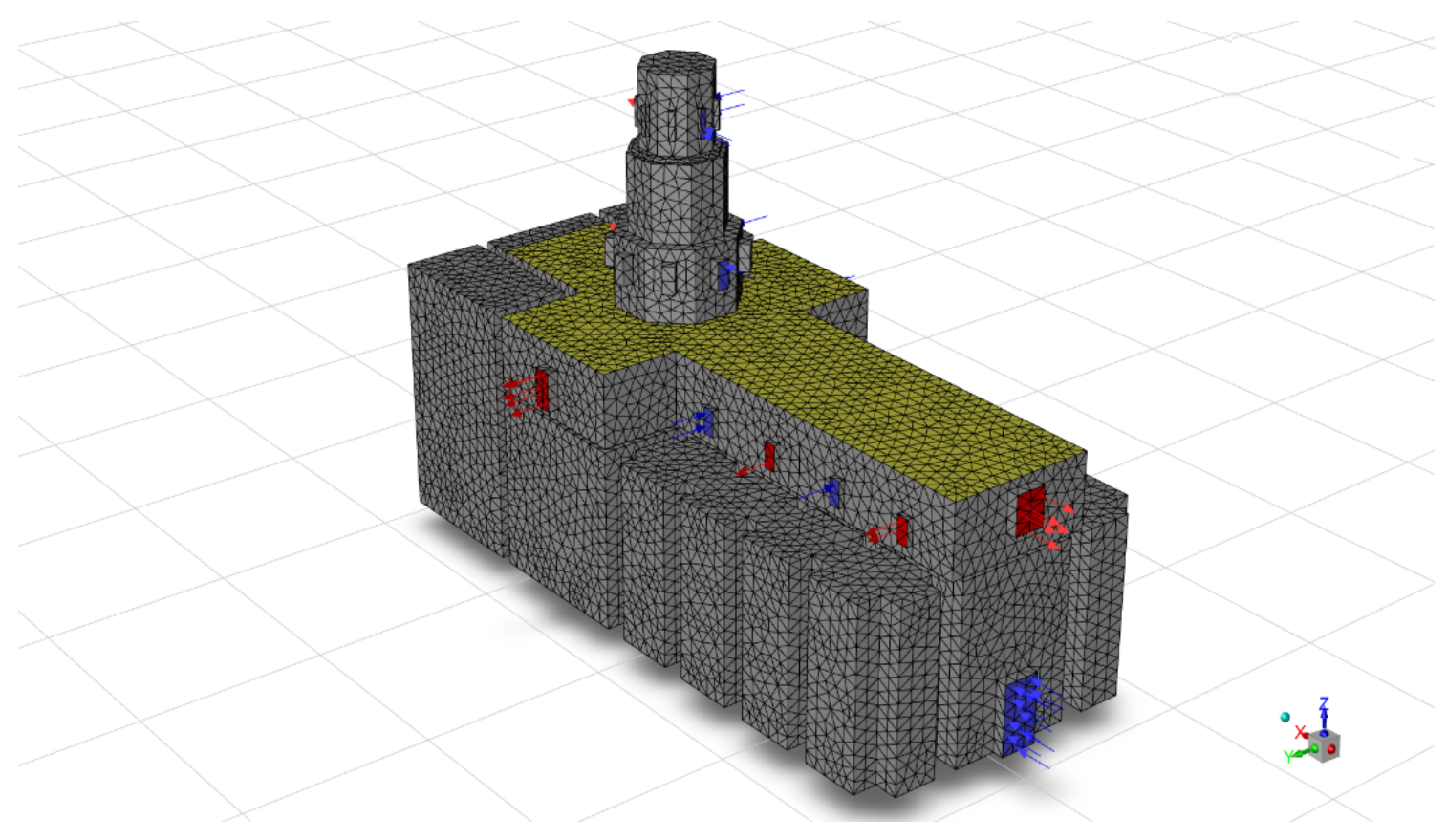

Figure 3. Finite element model used in calculations.

Due to the location of the building in the urban fabric, all the enclosures are not exposed to the outside and to sunlight with the same intensity. This has been taken into account in the calculations. In Figure 4, those faces of the model that are most exposed have been indicated in red. 


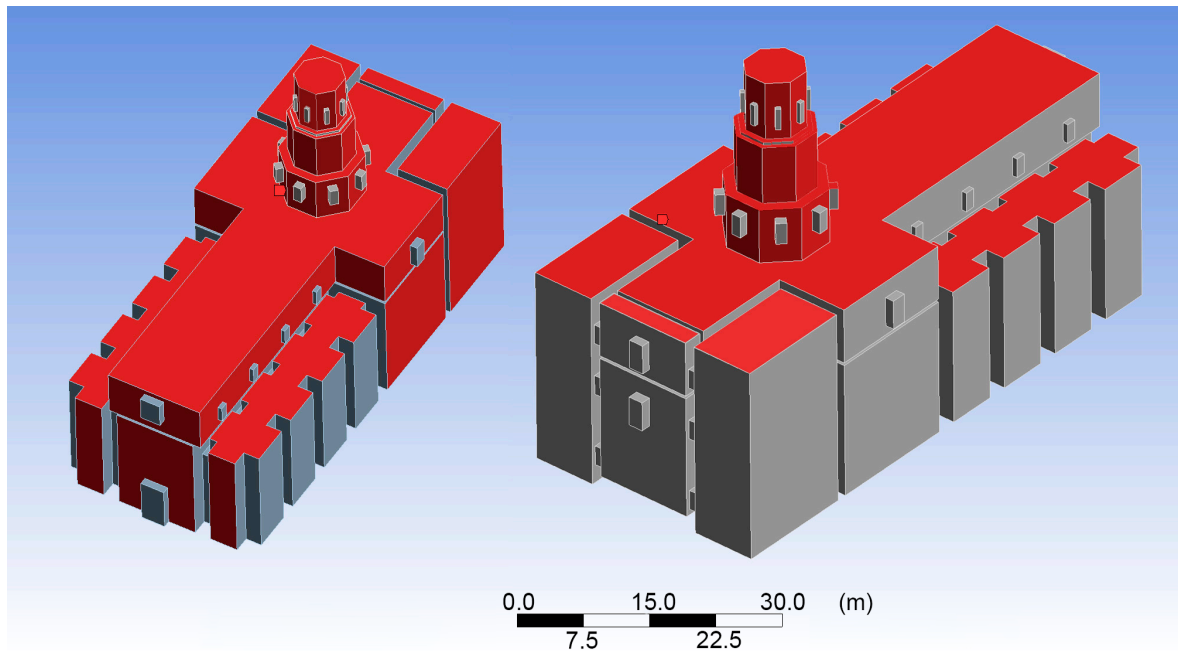

Figure 4. Surfaces with a high degree of exposure to the elements (red colour).

The air volume of the interior of the building has been modelled, considering an average thickness of the facade walls of $85 \mathrm{~cm}$ with a calcareous stone material, since the walls are composed of masonry. In order to simulate both the temperature and the relative humidity of the air, a mixed material has been specified that takes into account the phase changes that occur with evaporation or condensation of the air as a function of temperature. Table 4 shows the values of the main properties of the materials used. Table 5 shows the setup details. The film coefficients used inside the building are $35 \mathrm{~W} \cdot \mathrm{m}^{-2} \cdot \mathrm{K}^{-1}$ as it is a natural convection analysis, where the values are usually between 5-37 [49].

Table 4. Physical properties of the materials used.

\begin{tabular}{ccc}
\hline Property & Mixture Air & Stone \\
\hline Density $\left(\mathrm{kg} \cdot \mathrm{m}^{-3}\right)$ & incompressible & 2800 \\
Viscosity $\left(\mathrm{kg} \cdot \mathrm{m}^{-1} \cdot \mathrm{s}^{-1}\right)$ & $1.72 \times 10^{-5}$ & - \\
Conductivity $\left(\mathrm{W} \cdot \mathrm{m}^{-1} \cdot \mathrm{K}^{-1}\right)$ & 0.0454 & 2.25 \\
Specific heat $\left(\mathrm{J} \cdot \mathrm{kg}^{-1} \cdot \mathrm{K}^{-1}\right)$ & 1006.43 & 856 \\
Emissivity & 1 & 0.92 \\
\hline
\end{tabular}

Table 5. Setup details of CFD simulations.

\begin{tabular}{lll}
\hline Location & Type & Details \\
\hline Ceiling, Floor, Walls & Wall & $\begin{array}{l}\text { No-slip shear condition, stationary wall, with roughness } \\
\text { constant of } 0.5 .\end{array}$ \\
Air & Fluid & $\begin{array}{l}\text { Mixture material with species }\left(\mathrm{H}_{2} \mathrm{O} \text {, air). }\right. \\
\text { Inlet holes }\end{array}$ \\
Inlet & $\begin{array}{l}\text { Velocity magnitude: } 0.05 \mathrm{~m} \cdot \mathrm{s}^{-1} \text {. Turbulent intensity: } 5 \%, \\
\text { Turbulent viscosity ratio: } 10 .\end{array}$ \\
Outlet holes & Outlet & $\begin{array}{l}\text { Gauge pressure (pascal): } 0 . \text { Backflow turbulent intensity: } \\
5 \% . \text { Backflow turbulent viscosity ratio: } 10\end{array}$ \\
\hline
\end{tabular}

The physical models used in the calculations have been: Energy, Viscous (Realizable k-epsilon with standard wall function), Radiation (S2S) with solar load in Lliria (Valencia, Spain), and Species (Species Transport, to simulate relative humidity). In all the simulations calculated, no less than 500 iterations were executed, although the solution usually converges to less than 100.

Following the CFD software theory guide [26], conduction heat transfer is governed by Fourier's Law (Equation (1)), where $\mathrm{K}$ is the thermal conductivity and $\nabla T$ is the temperature gradient. Fourier's law states that the heat transfer rate is directly proportional 
to the gradient of temperature. The software computes conduction in all fluid and solid zones when the energy equation is activated.

$$
q_{\text {conduction }}=-K \nabla T
$$

Convection, which simulates the natural convection of the air (Equation (2)) and radiation, which simulates the radiation of the environment (Equation (3)), is considered for the thermal condition of the walls. Here, $h_{\text {ext }}$ is the outside heat transfer coefficient, $T_{\text {ext }}$ the outside temperature, $T_{w}$ wall temperature, external emissivity $\varepsilon_{e x t}$, and $\sigma$ the Stefan-Boltzmann constant $\left(5.6704 \times 10^{-8} \mathrm{~W} \cdot \mathrm{m}^{-2} \cdot \mathrm{K}^{-4}\right)$.

$$
\begin{aligned}
& q_{\text {conv }}=h_{\text {ext }}\left(T_{\text {ext }}-T_{w}\right) \\
& q_{\text {rad }}=\varepsilon_{\text {ext }} \sigma\left(T_{\infty}^{4}-T_{w}^{4}\right)
\end{aligned}
$$

For the combined study of these two parameters, a mixed system of boundary conditions is used (Equation (4)).

$$
q_{\text {mixed }}=h_{\text {ext }}\left(T_{\text {ext }}-T_{w}\right)+\varepsilon_{\text {ext }} \sigma\left(T_{\infty}^{4}-T_{w}^{4}\right)
$$

Natural convection occurs when fluid density is temperature dependent and heat is added to the fluid. Flow is induced by gravitational force acting on density differences. When gravity is activated, the pressure gradient and body force terms in the momentum equation are rewritten as in Equation (5), with $p^{\prime}=p-p_{0} g x$. The radiation model selected must be appropriate for the optical thickness of the system being simulated. Surface to surface model (S2S) is selected; when optical thickness is equal to zero, S2S has comparable accuracy with Discrete ordinates model (DO) at less computational expense.

$$
-\frac{\partial p}{\partial x}+p g \rightarrow \frac{\partial p^{\prime}}{\partial x}+\left(p-p_{0}\right) g
$$

The energy equation is solved in the following form:

$$
\frac{\partial(\rho E)}{\partial t}+\nabla \cdot[V(\rho E+p)]=\nabla \cdot\left[K_{e f f} \nabla T-\sum_{j} h_{j} J_{j}+\tau_{e f f} \cdot V\right]+S_{h}
$$

From Equation (6), $\frac{\partial(\rho E)}{\partial t}$ is the part of unsteady, $\nabla \cdot[V(\rho E+p)]$ is convection, $K_{e f f} \nabla T$ is conduction, $\left.\sum_{j} h_{j} J_{j}+\tau_{e f f} \cdot V\right]+S_{h}$ is the species diffusion, $\tau_{e f f} \cdot V$ is the viscous dissipation, and $S_{h}$ the enthalpy source.

In some other cases, the problem can be studied by separating it into two sections: the heat transfer in fluid, and the heat transfer in solid [50]. In this case, convection heat transfer results from fluid motion, where the heat transfer rate is coupled to the fluid flow solution; the rate of heat transfer is strongly dependent on fluid velocity and fluid properties, and fluid properties may vary significantly with temperature. Also, the velocity depends on the viscosity of the fluid [51].

\subsection{Infrared Thermography (IRT)}

In addition to the real data from the sensors, an IRT campaign is also set up inside the building. In this study, a FLIR E95 camera has been used. It produces thermographic pictures at a resolution of $464 \times 348$ pixels, with a temperature range of -20 to $+120^{\circ} \mathrm{C}$ and an accuracy of $\pm 2{ }^{\circ} \mathrm{C}$ or $\pm 2 \%$ of reading for ambient temperature $15^{\circ} \mathrm{C}$ to $35^{\circ} \mathrm{C}$ and object temperature above $0{ }^{\circ} \mathrm{C}$ [52].

The thermographic pictures were subsequently processed with FLIR Tools software, which can adjust the colour palette, temperature range, distance, as well as calculate the values of maximum, minimum, average temperatures in the selected areas and the specific 
temperature of the points where the sensors are located. All devices were appropriately calibrated before the measurements according to the operation manual. The emissivity values of the most common construction materials are over $90 \%$, and in our study, have been taken 0.95 , therefore, it is expected that the results obtained from thermographic measurements are reliable [53] and the emissivity is practically constant for non-metallic materials [54].

\section{Results and Discussion}

\subsection{Real Data with Sensors}

The data recorded by the sensors have allowed a global vision of the temperature and relative humidity of the building for a year, between August 2019 and August 2020 (Figure 5). This figure shows that the outdoor temperatures are included in a wide range during all the months of the year, between 5 and $40^{\circ} \mathrm{C}$. However, for each month, the average temperature usually varies $\pm 7^{\circ} \mathrm{C}$. The interior temperatures, however, are limited in a much smaller interval, $\pm 5{ }^{\circ} \mathrm{C}$ with respect to the average of each month. This range of indoor temperatures is lower in the summer and winter months and is higher in the spring and fall months.

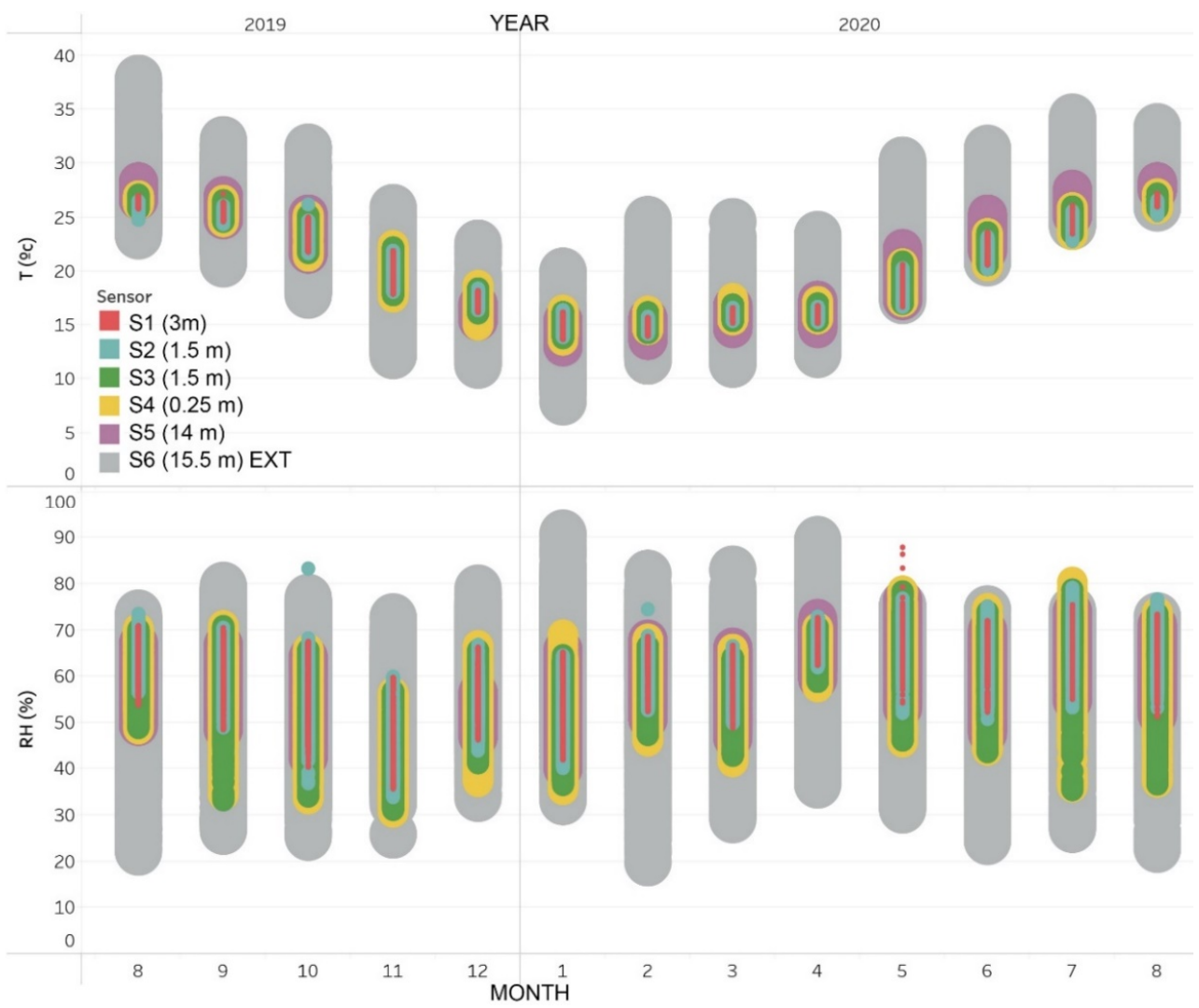

Figure 5. Overview of Temperature and Relative Humidity for each month.

Regarding relative humidity, Figure 5 shows how the range of outdoor values is very wide in all months of the year. The range of relative humidity inside the building is also very wide and variable.

The average temperature $\mathrm{T}\left({ }^{\circ} \mathrm{C}\right)$ has been calculated for all the months of the year (Table 6). The minimum-maximum temperature gradient of the sensors inside the building has been graphed in a blue-red colour scale. It is observed that the months of June to October correspond to the hottest and the months of December to April to the coldest, adjusting to the Mediterranean climate. 
Table 6. Average temperature $\mathrm{T}\left({ }^{\circ} \mathrm{C}\right)$ registered by the sensors.

\begin{tabular}{|c|c|c|c|c|c|c|c|c|c|c|c|c|}
\hline Sensor (Heigh) & Jan & Feb & Mar & Apr & May & Jun & Jul & Aug & Sep & Oct & Nov & Dec \\
\hline S1 (3 m) & 14.5 & 15.0 & 16.0 & 15.8 & 18.9 & 21.9 & 24.9 & 26.6 & 25.4 & 23.6 & 19.7 & 17.0 \\
\hline $\mathrm{S} 2(1.5 \mathrm{~m})$ & 14.8 & 15.1 & 16.0 & 15.9 & 18.6 & 21.5 & 24.2 & 25.7 & 25.0 & 23.3 & 19.8 & 17.1 \\
\hline S3 (1.5 m) & 14.7 & 15.4 & 16.3 & 16.1 & 19.0 & 21.9 & 24.9 & 26.6 & 25.5 & 23.7 & 19.8 & 17.1 \\
\hline $\mathrm{S} 4(0.25 \mathrm{~m})$ & 15.0 & 15.5 & 16.5 & 16.4 & 19.1 & 21.9 & 24.8 & 26.6 & 25.6 & 23.8 & 20.0 & 17.2 \\
\hline S5 (14 m) & 13.8 & 14.9 & 15.9 & 15.8 & 20.1 & 23.3 & 26.4 & 27.7 & 25.7 & 24.1 & 19.5 & 16.2 \\
\hline S6 (15.5 m) EXT & 11.9 & 15.1 & 15.2 & 16.2 & 22.1 & 24.7 & 27.9 & 28.6 & 25.1 & 22.3 & 16.9 & 14.8 \\
\hline
\end{tabular}

Similarly, the average relative humidity $\mathrm{RH}(\%)$ for each month is shown in Table 7. The relative humidity data outside the building (sensor S6) indicates that in the hot period the values were lower (56.2\% in June) and higher in the winter months (63.1\% in January). However, inside the building, the months of April to September have registered values of relative humidity clearly higher than the months of October to January. It should be borne in mind that due to the Sars-Cov-2 virus and the disease that causes COVID-19, in Spain there was confinement, mobility restrictions, and limitation of religious acts with a significant number of attendees (such as masses, in this case) since the end of March 2020, so the building was closed and unused until July. This coincides with the increase in relative humidity that can be seen during these months.

Table 7. Average relative humidity RH (\%) registered by the sensors.

\begin{tabular}{|c|c|c|c|c|c|c|c|c|c|c|c|c|}
\hline Sensor (Heigh) & Jan & Feb & Mar & Apr & May & Jun & Jul & Aug & Sep & Oct & Nov & Dec \\
\hline S1 (3 m) & 55.2 & 62.9 & 59.8 & 67.9 & 69.1 & 65.6 & 69.9 & 65.0 & 62.7 & 55.7 & 45.9 & 55.3 \\
\hline $\mathrm{S} 2(1.5 \mathrm{~m})$ & 54.3 & 62.7 & 59.8 & 67.9 & 70.5 & 67.3 & 72.5 & 68.0 & 63.9 & 56.4 & 45.4 & 54.5 \\
\hline $\mathrm{S} 3(1.5 \mathrm{~m})$ & 52.1 & 59.7 & 56.4 & 65.2 & 66.7 & 63.2 & 67.9 & 62.1 & 59.4 & 52.0 & 42.1 & 52.3 \\
\hline $\mathrm{S} 4(0.25 \mathrm{~m})$ & 51.8 & 59.4 & 56.4 & 65.0 & 67.3 & 64.0 & 68.8 & 62.2 & 59.3 & 51.9 & 41.8 & 51.8 \\
\hline S5 (14 m) & 54.8 & 61.4 & 58.3 & 66.3 & 64.8 & 60.7 & 65.0 & 60.4 & 59.9 & 53.6 & 46.6 & 52.6 \\
\hline S6 (15.5 m) EXT & 63.1 & 60.8 & 60.7 & 68.7 & 57.8 & 56.2 & 58.7 & 56.5 & 61.0 & 55.3 & 48.9 & 59.4 \\
\hline
\end{tabular}

Likewise, the accumulated precipitation each month is shown with data from AEMET (State Meteorological Agency of Spain) [55] in order to observe the characteristic rain periods (Table 8). The months from January to April, except February, have been the rainiest.

Table 8. Rain (mm). Source: AEMET (State Meteorological Agency of Spain).

\begin{tabular}{lcccccccccccc}
\hline & Jan & Feb & Mar & Apr & May & Jun & Jul & Aug & Sep & Oct & Nov & Dec \\
\hline Precipitation & 105.4 & 2.0 & 94.8 & 81.4 & 23.6 & 0.0 & 8.8 & 59.4 & 56.8 & 20.4 & 4.6 & 38.8 \\
\hline
\end{tabular}

Various authors $[7,19]$ have tried to establish criteria to identify the areas of buildings or the most significant moments in which condensation may occur and increase the risk of deterioration of construction materials. There are three parameters that indicate a greater risk of condensation: (i) temperature, since when it is low there is a greater probability that condensation will occur; (ii) the difference between the temperature $\mathrm{T}$ and the dew temperature $\mathrm{T}_{\mathrm{D}}$, since condensations occur if $\mathrm{T}_{\mathrm{D}}>\mathrm{T}$; (iii) and the renewal of air in the space to be studied, since an air renewal reduces the saturation of water vapor and, therefore, reduces condensation.

With these premises, a Risk index (Equation (7)) has been established to combine the three parameters. Factor (ii) is considered the most determining and has been analysed with $\alpha=50 \%$ of the score. Factor (i) is also important and is valued with $\beta=40 \%$. Factor (iii) is valued with $\gamma=10 \%$ due to the little influence of air renewal in a building with such a large volume of air.

$$
\text { Risk Index }=\alpha \cdot R_{T}+\beta \cdot R_{D}+\gamma \cdot R_{V}
$$

where $R_{T}$ is the risk of condensation due to ambient temperature, assigning in this case the value 1 at $0{ }^{\circ} \mathrm{C}$ and the value 0 at $40{ }^{\circ} \mathrm{C}$ and interpolating linearly for intermediate values. $R_{D}$ is the risk of condensation due to the proximity of the ambient temperature with the dew 
temperature, assigning the value 1 for $T-T_{D}=0$ and a value of 0 for $T-T_{D}=30$ and interpolating linearly. Finally, $R_{V}$ is the risk of condensation due to air renewal, assigned a value of 0.9 during confinement months (April to July), 0.75 to very cold or very hot months (August, September, December, January, February, March) where ventilation is not provided due to weather conditions, and 0.5 points to the rest of the months (October and November).

Table 9 shows how the risk of condensation inside the building is higher in the months of January to May, but especially in April, coinciding with relatively low temperatures, high relative humidity and little air renewal due to the restrictions of mobility imposed by COVID-19. Figure 6 shows in colour scale (green-red) the risk of condensation for each of the five sensors inside the building. It is a graph that relates temperature $\left(\mathrm{T}\left({ }^{\circ} \mathrm{C}\right)\right.$ ) and relative humidity (RH (\%)). In addition, the data of each sensor is superimposed on the data of all the sensors (grey colour) to be able to compare each sensor and to know which areas of the graph it covers.
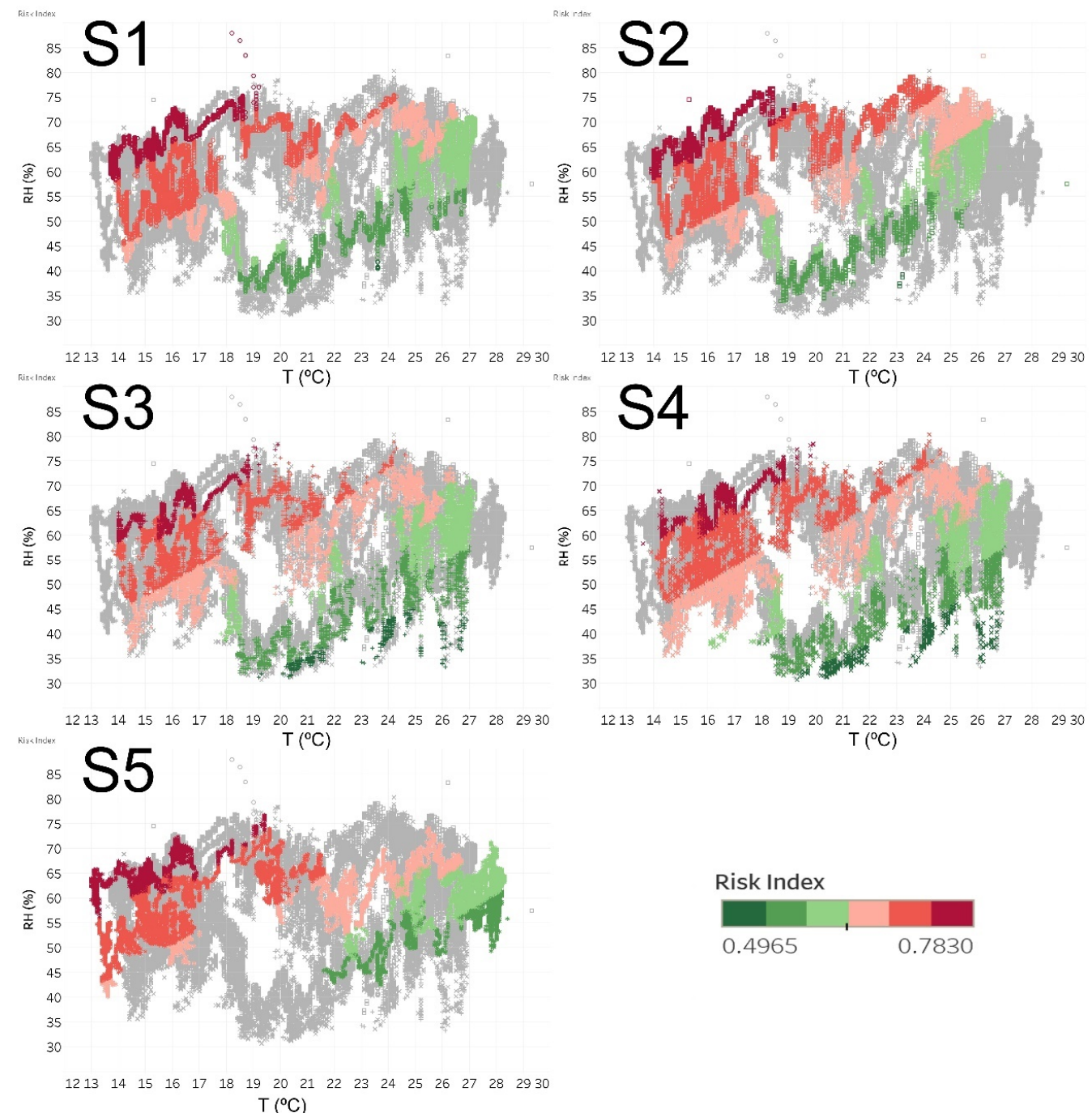

Figure 6. Comparison of the Risk index for each sensor (colour scale) on the Temperature-Relative Humidity graph. 
Table 9. Risk index of condensation inside the building.

\begin{tabular}{|c|c|c|c|c|c|c|c|c|c|c|c|c|}
\hline Sensor (Heigh) & Jan & Feb & Mar & Apr & May & Jun & Jul & Aug & Sep & Oct & Nov & Dec \\
\hline S1 (3 m) & 0.72 & 0.74 & 0.72 & 0.76 & 0.73 & 0.69 & 0.67 & 0.62 & 0.63 & 0.60 & 0.60 & 0.69 \\
\hline $\mathrm{S} 2(1.5 \mathrm{~m})$ & 0.71 & 0.74 & 0.72 & 0.76 & 0.74 & 0.70 & 0.68 & 0.64 & 0.63 & 0.60 & 0.60 & 0.69 \\
\hline $\mathrm{S} 3(1.5 \mathrm{~m})$ & 0.71 & 0.72 & 0.70 & 0.75 & 0.72 & 0.68 & 0.66 & 0.61 & 0.61 & 0.58 & 0.58 & 0.68 \\
\hline $\mathrm{S} 4(0.25 \mathrm{~m})$ & 0.70 & 0.72 & 0.70 & 0.74 & 0.72 & 0.68 & 0.66 & 0.61 & 0.61 & 0.58 & 0.58 & 0.68 \\
\hline $\mathrm{S} 5(14 \mathrm{~m})$ & 0.72 & 0.73 & 0.71 & 0.75 & 0.70 & 0.66 & 0.64 & 0.59 & 0.61 & 0.58 & 0.59 & 0.69 \\
\hline
\end{tabular}

\subsection{Computational Fluid Dynamics (CFD) Simulation}

The most extreme cases have been simulated, such as the hottest day (maximum outside temperature) and the coldest day (minimum outside temperature).

The winter case occurred on 20 January 2020 at 8:00 p.m., with an outdoor temperature of $7.9^{\circ} \mathrm{C}$ and a $\mathrm{RH} 78.8 \%$, data that have been used as boundary conditions (BC). With these data, in Figure 7 the temperature and relative humidity inside the building have been simulated. Three planes are graphed: longitudinal ZX plane along the axis of the building and two horizontal XY planes (1 $\mathrm{m}$ and $16 \mathrm{~m}$ high). The values are maintained with little variation, except in the vicinity of the openings of doors and windows, as well as the walls.

Table 10 shows the comparison between the temperature and relative humidity data recorded by the sensors and those obtained in the CFD simulation for the winter case. Thus, the table shows, for each sensor, the value of the temperature and relative humidity recorded and the value obtained in the CFD simulation at the same location. In this case, the software provides a confidence interval and not an exact value. Also, the difference is showed if the sensor value is not in the confidence interval of the CFD. For temperatures, the biggest difference is $0.03{ }^{\circ} \mathrm{C}$. In the case of relative humidity, the biggest difference is $1.3 \%$. In both cases, the simulation data is very accurate.

Table 10. Comparison of temperature and relative humidity in the case of winter.

\begin{tabular}{lcccccc}
\hline Sensor (Heigh) & $\begin{array}{c}\text { T }\left({ }^{\circ} \mathbf{C}\right) \\
\text { Sensor }\end{array}$ & $\begin{array}{c}\text { T }\left({ }^{\circ} \mathbf{C}\right) \\
\text { CFD }\end{array}$ & $\begin{array}{c}\text { Accuracy } \\
\left({ }^{\circ} \mathbf{C}\right)\end{array}$ & $\begin{array}{c}\text { RH }(\%) \\
\text { Sensor }\end{array}$ & $\begin{array}{c}\text { RH (\%) } \\
\text { CFD }\end{array}$ & $\begin{array}{c}\text { Accuracy } \\
(\%)\end{array}$ \\
\hline S1 $(3 \mathrm{~m})$ & 14.1 & $14.08-14.30$ & In & 53.2 & $51-52$ & -1.2 \\
S2 $(1.5 \mathrm{~m})$ & 14.3 & $14.31-14.53$ & +0.01 & 52.3 & $50-51$ & -1.3 \\
S3 $(1.5 \mathrm{~m})$ & 14.1 & $14.08-14.30$ & In & 51.4 & $50-51$ & -0.4 \\
S4 $(0.25 \mathrm{~m})$ & 14.1 & $13.86-14.08$ & -0.03 & 52.1 & $51-52$ & -0.1 \\
S5 $(14 \mathrm{~m})$ & 13.4 & $13.43-13.65$ & +0.03 & 52.1 & $53-54$ & +0.9 \\
S6 $(15.5 \mathrm{~m})$ EXT & 7.9 & 7.9 & In & & 78.8 & In \\
\hline
\end{tabular}

The case studied for summer happened on 9 August 2019 at 5:40 p.m., with an outdoor temperature of $37.9^{\circ} \mathrm{C}$ and a $\mathrm{RH}$ of $22.6 \%$, data that have been used as boundary conditions. With these data, in Figure 8 the temperature and relative humidity inside the building have been simulated. On this occasion, the sunlight and the different surfaces of the building that are more or less exposed to the elements cause more significant temperature differences than in the case of winter. The upper area of the roof and the south and west facades have higher temperatures, unlike other areas in the east and north, which are more protected.

Table 11 shows the comparison between the temperature and relative humidity data recorded by the sensors and those obtained in the CFD simulation for the summer case. Also, the difference is showed if the sensor value is not in the confidence interval of the CFD. For temperatures, the biggest difference is $1.15^{\circ} \mathrm{C}$ for the $\mathrm{S} 1$ sensor, although in the rest the differences are much smaller. In the case of relative humidity, the greatest difference is $7.9 \%$ for the $\mathrm{S} 2$ sensor, but for the rest the differences are minimal (less than $1 \%$ ). Therefore, in both cases, the simulation data is also very accurate.

These real values that differ from what is expected from CFD simulations should be studied carefully because they could indicate critical zones or moments.

Figure 9 shows a comparison of the CDF simulations for the summer and winter cases 
studied, both for temperature and relative humidity. In addition, the horizontal XY plane is shown at a height of $1 \mathrm{~m}$ and the longitudinal $\mathrm{ZX}$ plane along the axis of the building. This comparison allows to analyse, qualitatively, what is the hygrothermal situation in the building in each case.

a)

b)
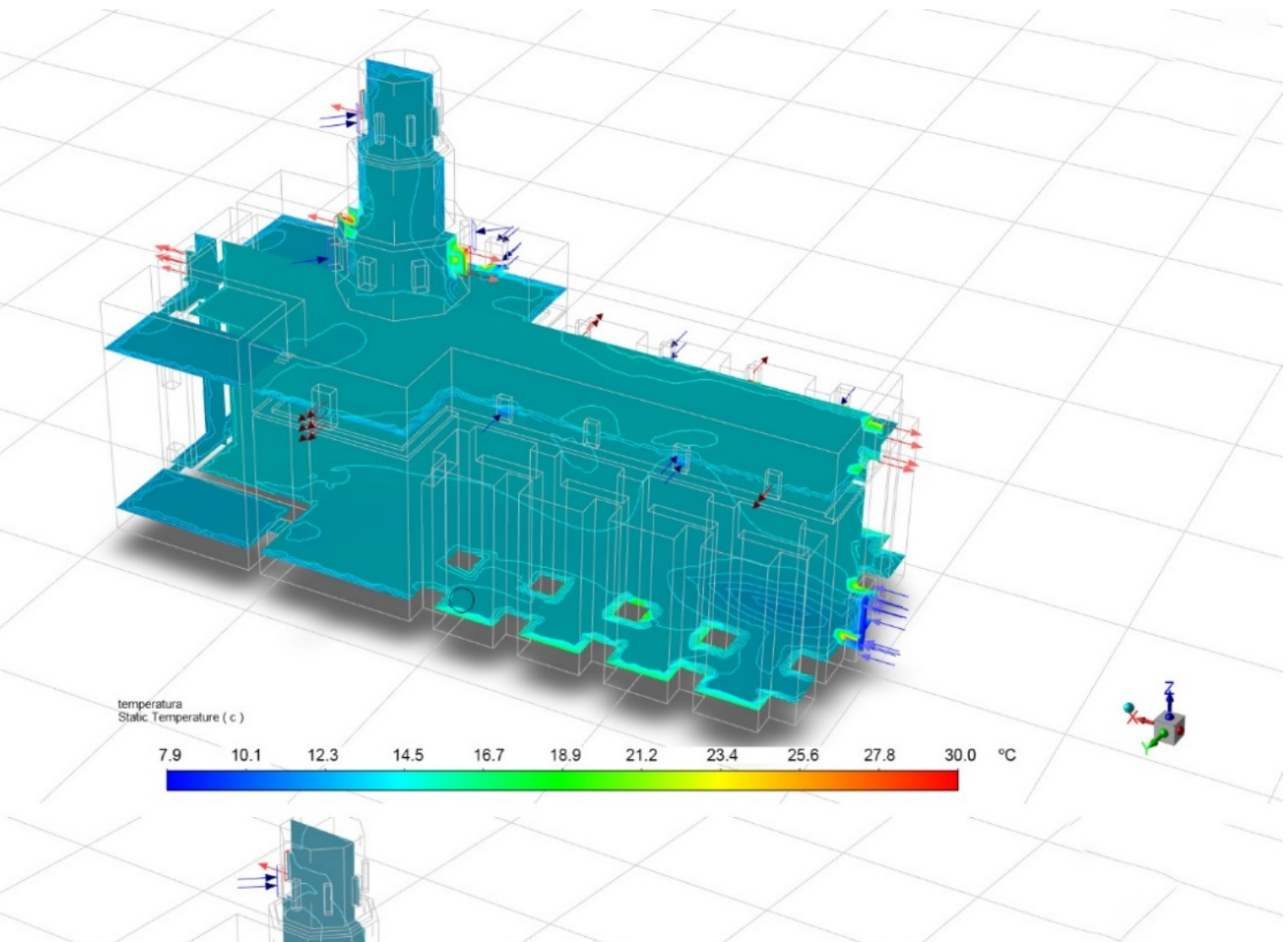

Relative Humididy ( \%)

$30.0 \quad 30.5$

$40.0 \quad 40.5$

50.0

$\begin{array}{lll}70.0 & 70.5 \quad 80.0 \quad \%\end{array}$

Figure 7. Winter CFD simulation perspective. (a) Temperatures and (b) relative humidity. 
Table 11. Comparison of temperature and relative humidity in the case of summer.

\begin{tabular}{lcccccc}
\hline Sensor (Heigh) & $\begin{array}{c}\text { T }\left({ }^{\circ} \mathbf{C}\right) \\
\text { Sensor }\end{array}$ & $\begin{array}{c}\text { T }\left({ }^{\circ} \mathbf{C}\right) \\
\text { CFD }\end{array}$ & $\begin{array}{c}\text { Accuracy } \\
\text { T }\left({ }^{\circ} \mathbf{C}\right)\end{array}$ & $\begin{array}{c}\text { RH (\%) } \\
\text { Sensor }\end{array}$ & $\begin{array}{c}\text { RH (\%) } \\
\text { CFD }\end{array}$ & $\begin{array}{c}\text { Accuracy } \\
\text { RH (\%) }\end{array}$ \\
\hline S1 $(3 \mathrm{~m})$ & 26.4 & $25.00-25.25$ & -1.15 & 64.5 & $63.30-63.75$ & -0.75 \\
S2 $(1.5 \mathrm{~m})$ & 25.3 & $25.00-25.25$ & -0.05 & 68.5 & $60.15-60.60$ & -7.90 \\
S3 $(1.5 \mathrm{~m})$ & 26.4 & $26.50-26.75$ & +0.10 & 62.1 & $61.50-61.95$ & -0.15 \\
S4 $(0.25 \mathrm{~m})$ & 26.2 & $26.25-26.50$ & +0.05 & 60.9 & $60.15-60.60$ & -0.30 \\
S5 $(14 \mathrm{~m})$ & 27.9 & $28.25-28.50$ & +0.35 & 50.9 & $50.25-50.75$ & -0.15 \\
S6 $(15.5 \mathrm{~m})$ EXT & 37.9 & 37.9 & & 22.6 & 22.6 & \\
\hline
\end{tabular}

a)

b)
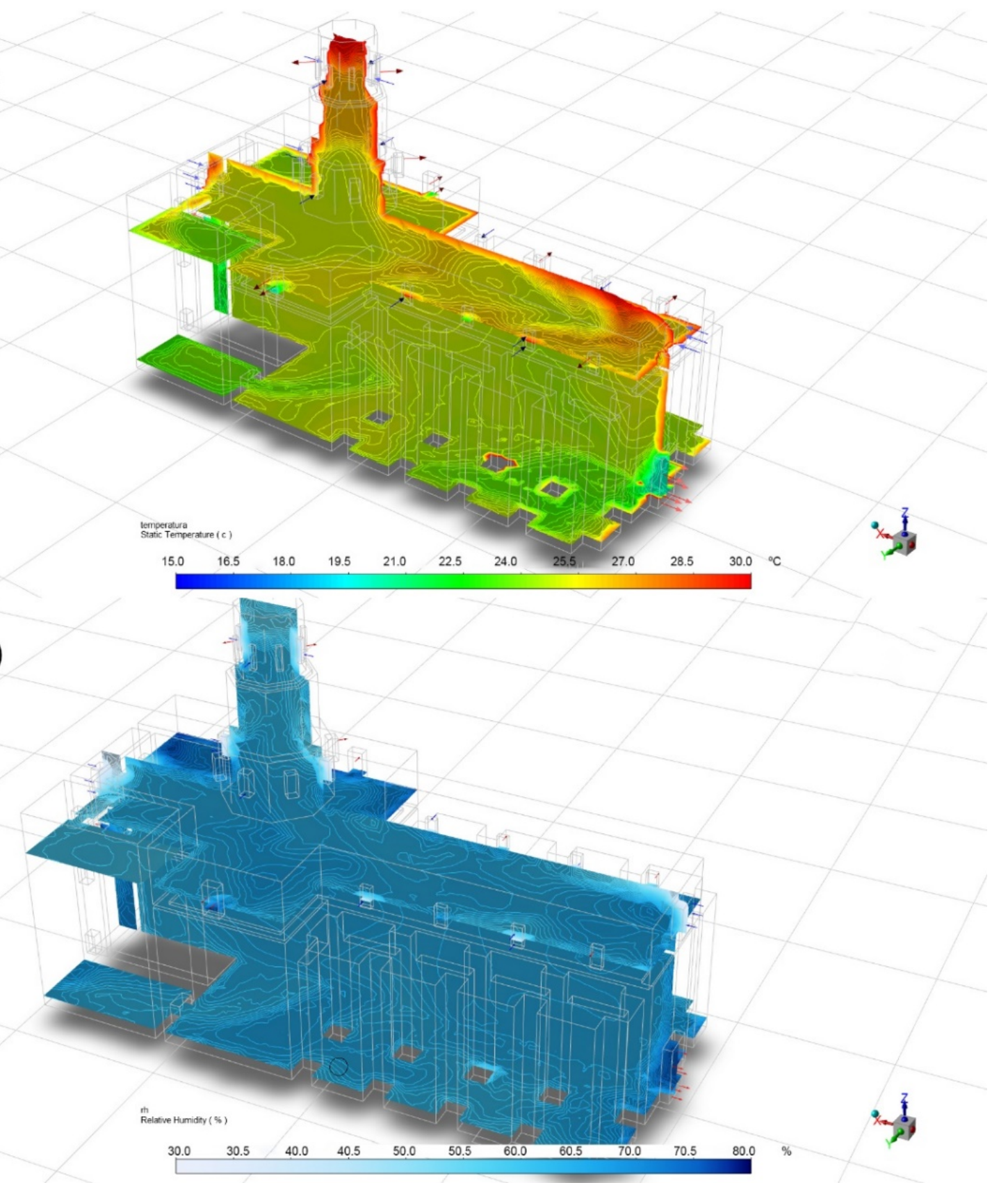

Figure 8. Summer CFD simulation perspective. (a) Temperatures and (b) relative humidity. 
WINTER

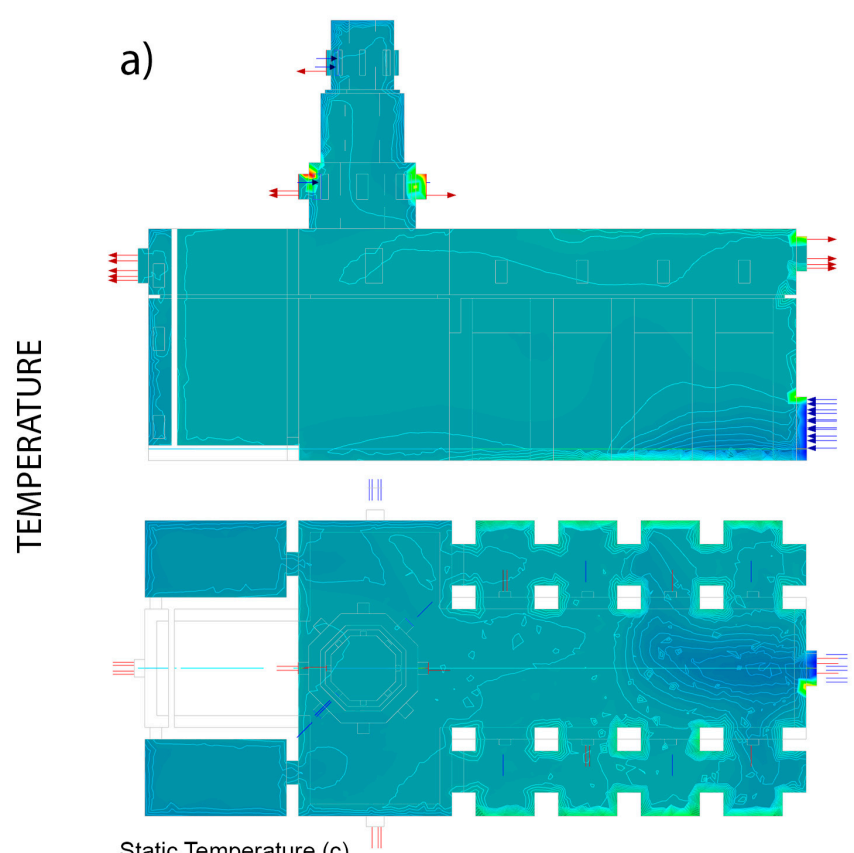

Static Temperature (c)
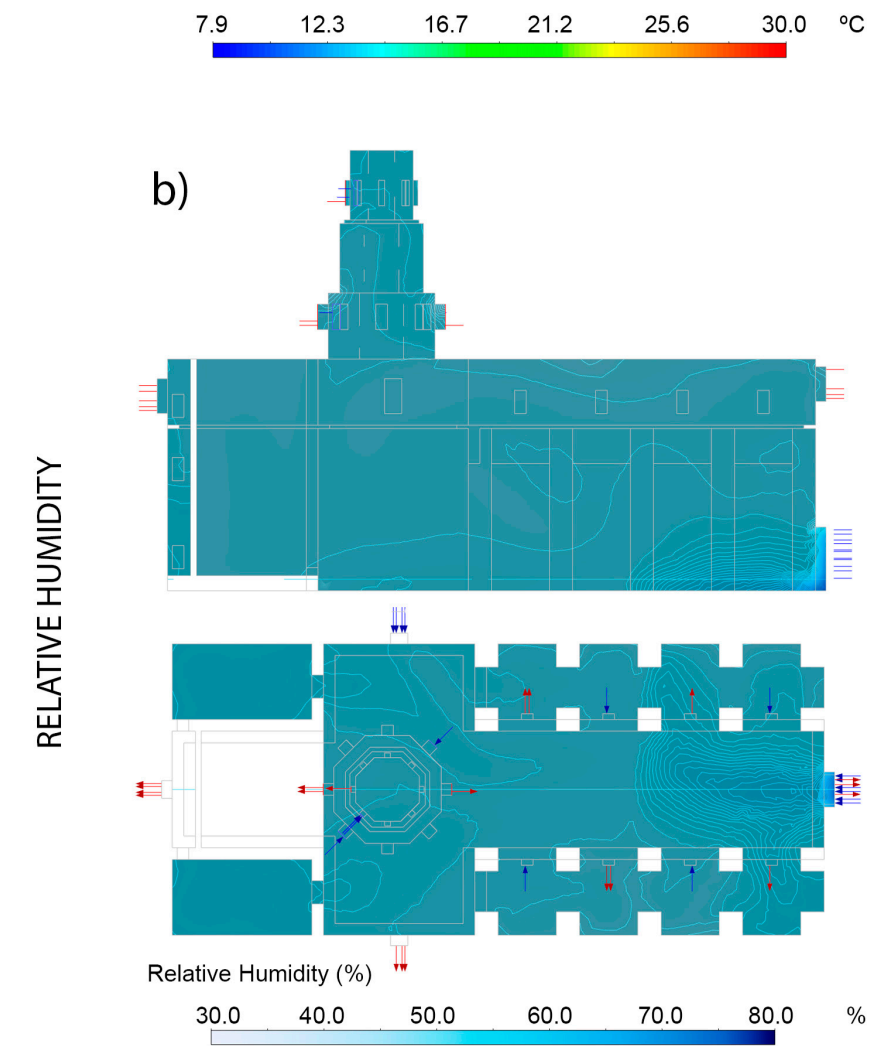

SUMMER

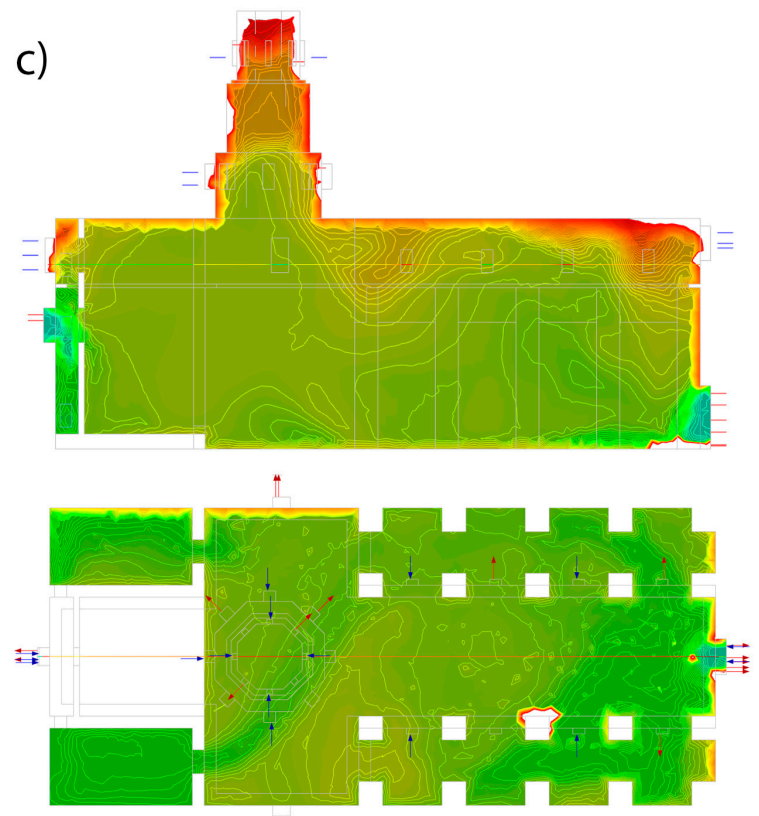

Static Temperature (c) "
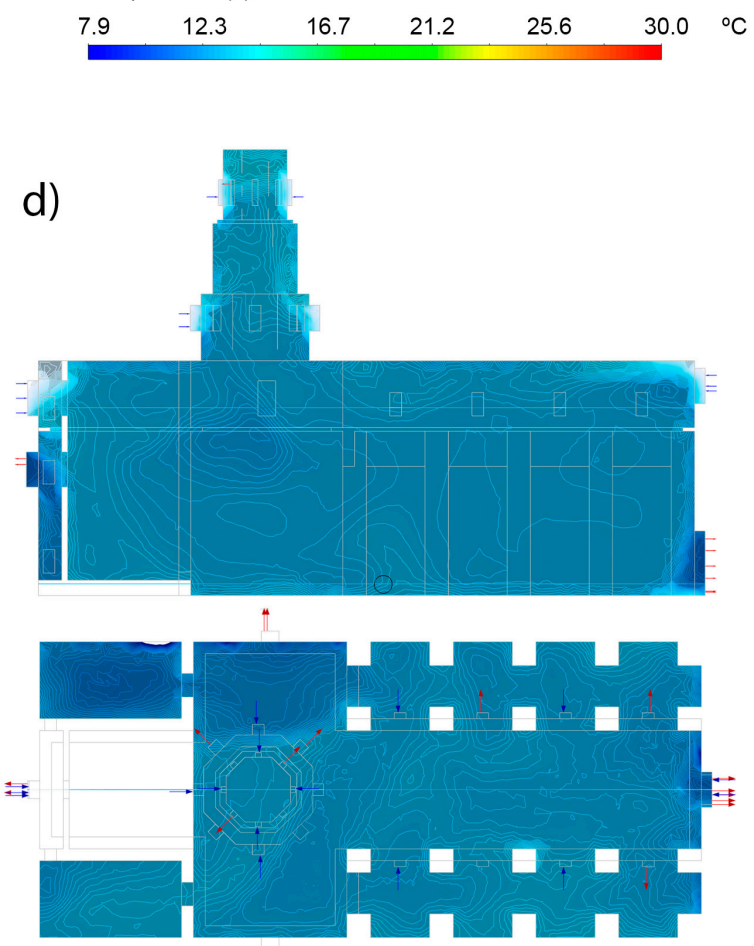

Relative Humidity (\%) "

$\begin{array}{llllll}30.0 & 40.0 & 50.0 & 60.0 & 70.0 & 80.0\end{array}$

Figure 9. Comparison of CFD simulations. $(\mathbf{a}) \mathrm{T}\left({ }^{\circ} \mathrm{C}\right)$ in winter, (b) RH $(\%)$ in winter, $(\mathbf{c}) \mathrm{T}\left({ }^{\circ} \mathrm{C}\right)$ in summer, $(\mathrm{d}) \mathrm{RH}(\%)$ in summer.

\subsection{Infrared Thermography (IRT)}

The thermograms shown in Figure 10 were taken on 24 June 2020 between 10:00 and 11:00 a.m. The points marked in the figure indicate the position of the sensors. Thermo- 
graphic pictures show the temperature distribution of the different surfaces. Likewise, the figure shows the temperature registered by the IRT in the region where each of the sensors is located inside the building.

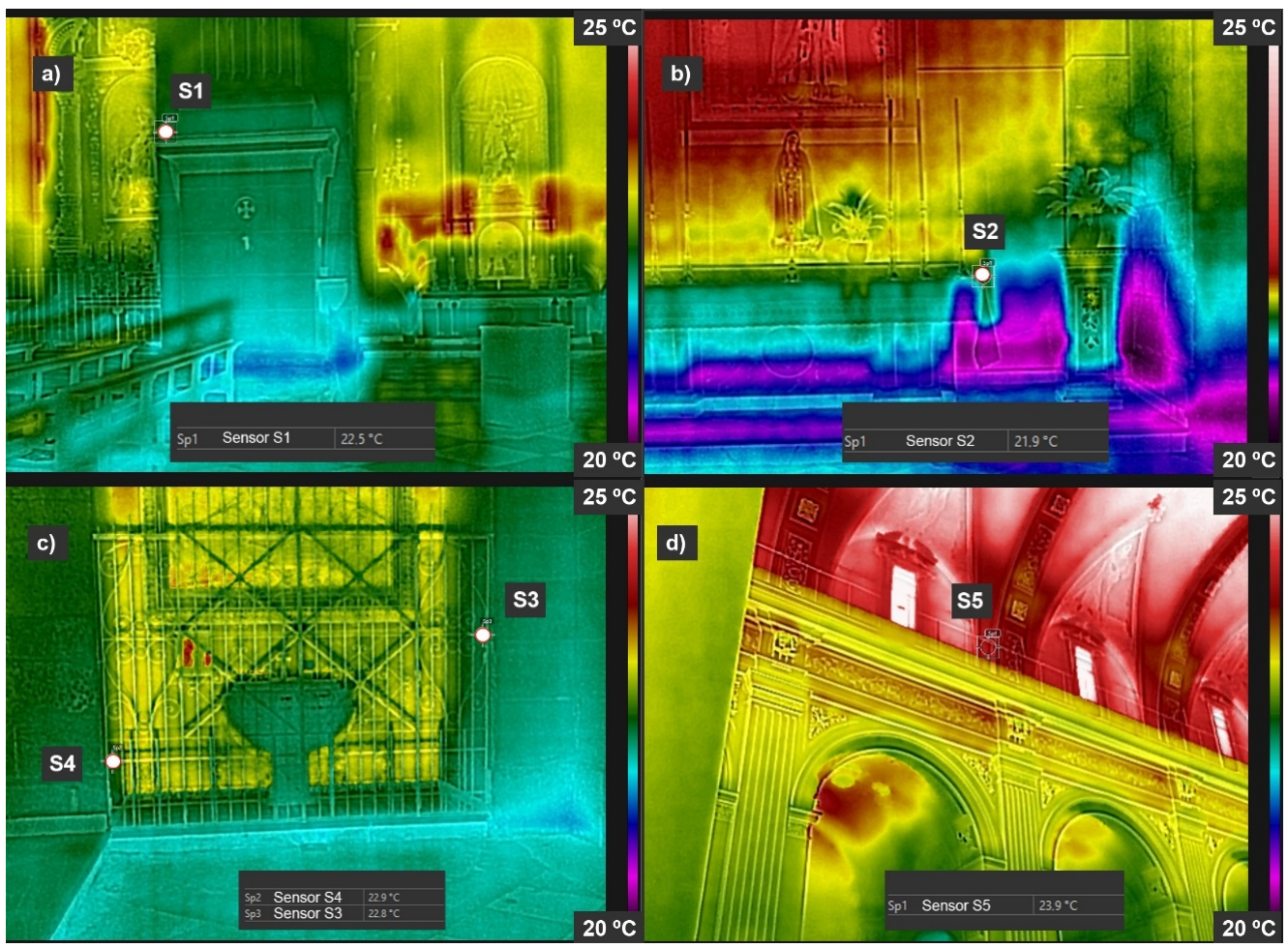

Figure 10. IRT pictures. (a) Sensor S1, (b) sensor S2, (c) sensors S3 and S4, (d) sensor S5.

In Figure 11, the CFD simulation is shown. In this case, the same temperature and relative humidity conditions were used as when the IRT pictures were taken, with the real values recorded by the sensors. These real values from the thermograms allow to complete the validation of the sensors and the CFD simulations. Table 12 compares the temperature values obtained by the sensors and those recorded by the CFD simulation and the IRT pictures, as well as the precision achieved in each case. Also, the difference is showed if the sensor value is not in the confidence interval of the CFD. It is observed that the differences between the temperature values of the sensors and those obtained by the $\mathrm{CDF}$ simulation are not greater than $0.5^{\circ} \mathrm{C}$. In the case of the temperatures recorded by infrared thermography, the differences with respect to the values obtained by the sensors are also very small, not greater than $0.3^{\circ} \mathrm{C}$.

Table 12. Comparison of temperature recorded by sensors, CFD and IRT.

\begin{tabular}{lccccc}
\hline \multicolumn{1}{c}{ Sensor (Heigh) } & $\begin{array}{c}\text { T }\left({ }^{\circ} \mathbf{C}\right) \\
\text { Sensor }\end{array}$ & $\begin{array}{c}\text { T }\left({ }^{\circ} \mathbf{C}\right) \\
\text { CFD }\end{array}$ & $\begin{array}{c}\text { Accuracy } \\
\text { CFD T }\left({ }^{\circ} \mathbf{C}\right)\end{array}$ & $\begin{array}{c}\text { T }\left({ }^{\circ} \mathbf{C}\right) \\
\text { IRT }\end{array}$ & $\begin{array}{c}\text { Accuracy } \\
\text { IRT T }\left({ }^{\circ} \mathbf{C}\right)\end{array}$ \\
\hline S1 $(3 \mathrm{~m})$ & 22.7 & $22.70-22.75$ & In & 22.5 & -0.2 \\
S2 $(1.5 \mathrm{~m})$ & 22.2 & $22.45-22.50$ & +0.25 & 21.9 & -0.3 \\
S3 $(1.5 \mathrm{~m})$ & 22.7 & $22.65-22.70$ & In & 22.8 & +0.1 \\
S4 $(0.25 \mathrm{~m})$ & 22.7 & $22.70-22.75$ & In & 22.9 & +0.2 \\
S5 $(14 \mathrm{~m})$ & 24.2 & $23.70-23.75$ & -0.50 & 23.9 & -0.3 \\
S6 $(15.5 \mathrm{~m})$ EXT & 24.9 & 24.9 & & & \\
\hline
\end{tabular}




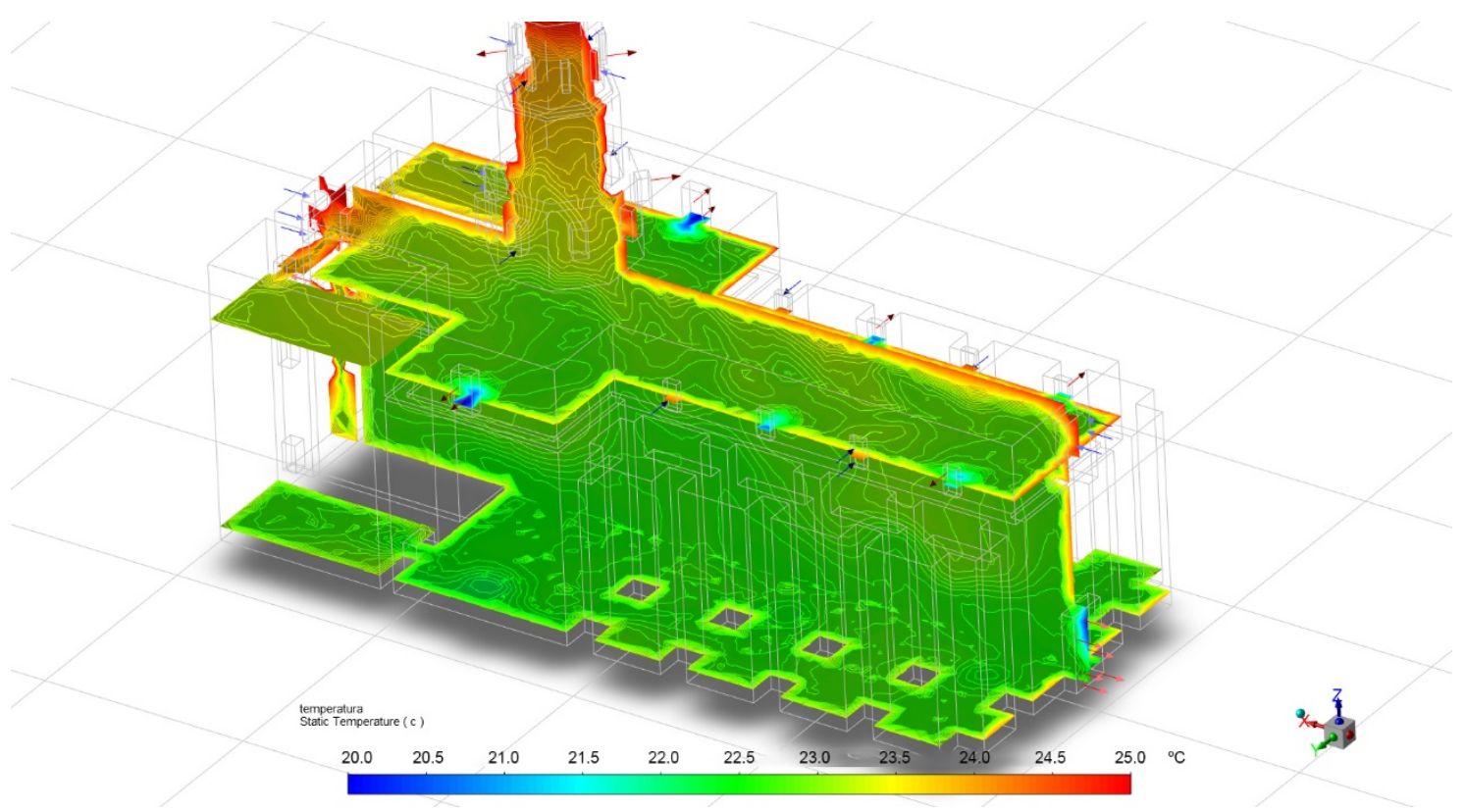

Figure 11. CFD simulation to compare results with sensors and IRT pictures.

\section{Conclusions}

This work has focused on the hygrothermal analysis of a heritage building over a period of 1 year using three NDTs: temperature and relative humidity data-loggers sensors, IRT thermographic pictures and CFD finite element simulations.

The proposed methodology consists of recording temperature and relative humidity values with sensors distributed at strategic points in the building. These actual values allow to verify and validate the CFD simulations, which cover the entire interior volume of the building. Likewise, infrared thermography allows to complete the verification of the simulations.

The more than 200,000 values of temperature and relative humidity registered by the sensors allow to obtain a clear vision of the hygrothermal evolution of the building. Outdoor temperatures are in a wide range during all months of the year, between 5 and $40{ }^{\circ} \mathrm{C}$. However, the interior temperatures are limited to a smaller interval, $\pm 7{ }^{\circ} \mathrm{C}$ with respect to the average temperature of each month. Also, this range of indoor temperatures is lower in the summer and winter months and is higher in the spring and autumn months.

The proposed methodology seeks to identify those areas of the building and when there is a high risk of condensation, which can affect the integrity of building materials and the healthiness of the interior environment. A Risk Index is established based on the temperature, the difference between temperature with respect to the dew temperature and the renewal of the air inside the building. For the case studied, the risk of condensation inside the building is greater in the months of January to May, but especially in April, coinciding with relatively low temperatures, high relative humidity and little air renewal due to the mobility restrictions imposed by COVID-19. However, in addition, when the height is greater inside the building, the risk of condensation increases.

The CFD simulations include the most representative physical models to represent the case studied, which includes energy, radiation with solar load, and phase changes in air to simulate relative humidity. The most representative cases, summer and winter, have been studied. The sections of the building generated in the simulations allow a first qualitative analysis of temperatures and relative humidity. A quantitative analysis has also been carried out by comparing the temperature and relative humidity data recorded by the sensors and those obtained in the CFD simulation. In the case of winter, the difference between the temperatures is 0.03 of a ${ }^{\circ} \mathrm{C}$. In the case of relative humidity, the biggest 
difference is $1.3 \%$. For the summer case, the largest temperature difference between the sensors and the CFD is $1.15^{\circ} \mathrm{C}$ for the $\mathrm{S} 1$ sensor, although in the rest the differences are much smaller. In the case of relative humidity, the biggest difference is $7.9 \%$ for the S2 sensor, but for the rest, the differences are also minimal (less than 1\%). Therefore, in both cases, the simulation data is very accurate.

Infrared thermography has completed the verification of CFD simulations. For this, the conditions when the thermographic images were taken have been modelled and the temperature values of the sensors, CFD and IRT have been compared. The differences between the temperature values of the sensors and those obtained by the CDF simulation are not greater than $0.5^{\circ} \mathrm{C}$. In the case of the temperatures recorded by infrared thermography, the differences with respect to the values obtained by the sensors are also very small, not greater than $0.3^{\circ} \mathrm{C}$.

Future works may address different applications of this methodology in heritage buildings, which are highly susceptible to humidity and condensation. A greater number of sensors will allow a better sensitivity of the hygrothermal analysis and greater control points of the CFD simulations. Even a transient study using CFD over time can be interesting to be able to be compared with the average data from the sensors. Likewise, an IRT campaign on different days of the year will provide more information and values to confront, achieving a better knowledge of reality and a better conservation of our heritage.

Author Contributions: Conceptualization, C.L.; methodology, C.L., J.V. and E.G.; software, C.L. and J.G.B.; validation, C.L.; formal analysis, C.L.; investigation, C.L., Á.M., M.E.T.; resources, J.G.B., M.E.T.; data curation, C.L. and M.E.T.; supervision, Á.M. and E.G.; writing-original draft preparation, C.L.; writing the revised draft of the manuscript, C.L., J.V., J.G.B. All authors have read and agreed to the published version of the manuscript.

Funding: This research received no external funding.

Acknowledgments: The authors wish to thank those responsible for the church of La Asunción de Llíria (Valencia, Spain) for their willingness and permission for this research for more than a year.

Conflicts of Interest: The authors declare no conflict of interest.

\section{References}

1. Sánchez-Aparicio, L.J.; Castro, Á.B.-D.; Conde, B.; García, P.C.; Ramos, L.F. Non-Destructive Means and Methods for Structural Diagnosis of Masonry Arch Bridges. Autom. Constr. 2019, 104, 360-382. [CrossRef]

2. Gil, E.; Mas, Á.; Lerma, C.; Torner, M.E.; Vercher, J. Non-Destructive Techniques Methodologies for the Detection of Ancient Structures under Heritage Buildings. Int. J. Arch. Herit. 2019, 1-17. [CrossRef]

3. Calia, A.; Leucci, G.; Masini, N.; Matera, L.; Persico, R.; Sileo, M. Integrated Prospecting in the Crypt of the Basilica of Saint Nicholas in Bari, Italy. J. Geophys. Eng. 2012, 9, 271-281. [CrossRef]

4. Carlomagno, G.M.; Di Maio, R.; Fedi, M.; Meola, C. Integration of Infrared Thermography and High-Frequency Electromagnetic Methods in Archaeological Surveys. J. Geophys. Eng. 2011, 8, S93-S105. [CrossRef]

5. Masini, N.; Persico, R.; Rizzo, E. Some Examples of GPR Prospecting for Monitoring of the Monumental Heritage. J. Geophys. Eng. 2010, 7, 190-199. [CrossRef]

6. Capineri, L.; Capitani, D.; Casellato, U.; Faroldi, P.; Grinzato, E.; Ludwig, N.; Olmi, R.; Priori, S.; Proietti, N.; Rosina, E.; et al. Limits and Advantages of Different Techniques for Testing Moisture Content in Masonry. Mat. Eval. 2011, 69, 111-116.

7. García-Morales, S.; Lopez-Gonzalez, L.; Collado-Gómez, A. Metodología de Inspección Higrotérmica para la Determinación de un Factor Intensidad de Evaporación en Edificios Históricos. Inf. Construcción 2012, 64, 69-78. [CrossRef]

8. Alexakis, E.; Delegou, E.T.; Labropoulos, K.; Apostolopoulou, M.; Ntoutsi, I.; Moropoulou, A. NDT as a Monitoring Tool of the Works Progress and the Assessment of Materials and Rehabilitation Interventions at the Holy Aedicule of the Holy Sepulchre. Constr. Build. Mater. 2018, 189, 512-526. [CrossRef]

9. Paoletti, D.; Ambrosini, D.; Sfarra, S.; Bisegna, F. Preventive Thermographic Diagnosis of Historical Buildings for Consolidation. J. Cult. Herit. 2013, 14, 116-121. [CrossRef]

10. Bradley, S. Preventive Conservation Research and Practice at the British Museum. J. Am. Inst. Conserv. 2005, 44, 159-173. [CrossRef]

11. Fertitta, G.; Di Stefano, A.; Fiscelli, G.; Giaconia, C.G. An Embedded Dataloggerwith a Fast Acquisition Rate for in-Vehicle Testing and Monitoring. In Proceedings of the Seventh Worksshop on Intelligent solutions in Embedded Systems, Ancora, Italy, 25-26 June 2009; pp. 105-110. 
12. Mccullagh, J.; Galchev, T.; Peterson, R.; Gordenker, R.; Zhang, Y.; Lynch, J.; Najafi, K. Long-term Testing of a Vibration Harvesting System for the Structural Health Monitoring of Bridges. Sens. Actr. A Phys. 2014, 217, 139-150. [CrossRef]

13. Abu-Zeid, N.; Botteon, D.; Cocco, G.; Santarato, G. Non-invasive Characterisation of Ancient Foundations in Venice Using the Electrical Resistivity Imaging Technique. NDT E Int. 2006, 39, 67-75. [CrossRef]

14. Martinho, E.; Alegria, F.C.; Dionísio, A.; Grangeia, C.; Almeida, F. 3D-resistivity Imaging and Distribution of Water Soluble Salts in Portuguese Renaissance Stone Bas-Reliefs. Eng. Geol. 2012, 142, 33-44. [CrossRef]

15. Leucci, G.; Persico, R.; Soldovieri, F. Detection of Fractures from GPR Data: The Case History of the Cathedral of Otranto. J. Geophys. Eng. 2007, 4, 452-461. [CrossRef]

16. Grossi, D.; Del Lama, E. Ultrasound Technique to Assess the Physical Conditions of the Monument to Ramos de Azevedo, City of São Paulo, Brazil. Rem Revista Escola de Minas 2015, 68, 171-176. [CrossRef]

17. Almeida, R.M.; Barreira, E.; Moreira, P. A Discussion Regarding the Measurement of Ventilation Rates Using Tracer Gas and Decay Technique. Infrastructures 2020, 5, 85. [CrossRef]

18. Varas-Muriel, M.; Garrido, M.I.M.; Fort, R. Monitoring the Thermal-Hygrometric Conditions Induced by Traditional Heating Systems in a Historic Spanish Church (12th-16th C). Energy Build. 2014, 75, 119-132. [CrossRef]

19. Vella, R.C.; Rey-Martínez, F.J.; Yousif, C.; Gatt, D. A Study of Thermal Comfort in Naturally Ventilated Churches in a Mediterranean Climate. Energy Build. 2020, 213, 109843. [CrossRef]

20. Nava, S.; Becherini, F.; Udisti, R.; Valli, G.; Vecchi, R.; Bernardi, A.; Bonazza, A.; Chiari, M.; García-Orellana, I.; Lucarelli, F.; et al. An integrated Approach to Assess Air Pollution Threats to Cultural Heritage in a Semi-Confined Environment: The Case Study of Michelozzo's Courtyard in Florence (Italy). Sci. Total Environ. 2010, 408, 1403-1413. [CrossRef]

21. Ponechal, R.; Krušinský, P.; Pisca, P.; Korenková, R. Simulation and measurement of microclimate in roof space on a gothic truss construction. In Proceedings of the MATEC Web of Conferences (27th Russian-Polish-Slovak Seminar, Theoretical Foundation of Civil Engineering (27RSP)), Rostov-on-Don, Russia, 17-21 September 2018. [CrossRef]

22. Garrido, M.I.M.; Ergenç, D.; Fort, R. Wireless Monitoring to Evaluate the Effectiveness of Roofing Systems Over Archaeological Sites. Sens. Actr. A Phys. 2016, 252, 120-133. [CrossRef]

23. Lourenço, P.B.; Luso, E.C.P.; De Almeida, M.G. Defects and Moisture Problems in Buildings from Historical City Centres: A Case Study in Portugal. Build. Environ. 2006, 41, 223-234. [CrossRef]

24. Awbi, H.B. Ventilation of Buildings, 2nd ed.; E \& FN Spon: New York, NY, USA, 2003.

25. Vercher, J.; Lerma, C.; Vidal, M.; Gil, E. Analysis of Energy Efficiency in Construction Solutions at the Façade-Slab Connection. Adv. Mater. Res. 2013, 787, 731-735. [CrossRef]

26. ANSYS Fluent Theory Guide. Chapter 5: Heat Transfer 15.2. Modeling Conductive and Convective Heat Transfer. 2020. Available online: https://ansyshelp.ansys.com/account/secured?returnurl=/Views/Secured/corp/v201/en/flu_th/flu_th_sec_hxfer_ theory.html (accessed on 16 November 2020).

27. Yusoff, W.F.M. The Effects of Various Opening Sizes and Configurations to Air Flow Dispersion and Velocity in Cross-Ventilated Building. J. Teknol. 2020, 82. [CrossRef]

28. Izadyar, N.; Miller, W.; Rismanchi, B.; Garcia-Hansen, V. A Numerical Investigation of Balcony Geometry Impact on Single-Sided Natural Ventilation and Thermal Comfort. Build. Environ. 2020, 177, 106847. [CrossRef]

29. Aflaki, A.; Hirbodi, K.; Mahyuddin, N.; Yaghoubi, M.; Esfandiari, M. Improving the Air Change Rate in High-Rise Buildings Through a Transom Ventilation Panel: A Case Study. Build. Environ. 2019, 147, 35-49. [CrossRef]

30. Nejat, P.; Jomehzadeh, F.; Hussen, H.M.; Calautit, J.; Majid, M.Z.A. Application of Wind as a Renewable Energy Source for Passive Cooling through Windcatchers Integrated with Wing Walls. Energies 2018, 11, 2536. [CrossRef]

31. Wang, J.; Wang, S.; Zhang, T.; Battaglia, F. Assessment of Single-Sided Natural Ventilation Driven by Buoyancy Forces through Variable Window Configurations. Energy Build. 2017, 139, 762-779. [CrossRef]

32. Moropoulou, A.; Avdelidis, N.; Mujumdar, A.S.; Delegou, E.T.; Alexakis, E.; Keramidas, V. Multispectral Applications of Infrared Thermography in the Diagnosis and Protection of Built Cultural Heritage. Appl. Sci. 2018, 8, 284. [CrossRef]

33. De Freitas, S.S.; De Freitas, V.P.; Barreira, E. Detection of Façade Plaster Detachments Using Infrared Thermography-A Nondestructive Technique. Constr. Build. Mater. 2014, 70, 80-87. [CrossRef]

34. Fitzner, B. Técnicas de Diagnóstico Aplicadas a la Conservación de los Materiales de Construcción en los Edificios Históricos; Junta de Andalucía: Seville, Spain, 1996.

35. Aguilar, R.; Noel, M.F.; Ramos, L.F. Integration of Reverse Engineering and Non-Linear Numerical Analysis for the Seismic Assessment of Historical Adobe Buildings. Autom. Constr. 2019, 98, 1-15. [CrossRef]

36. Arce, A.; Ramos, L.F.; Fernandes, F.M.; Sánchez-Aparicio, L.J.; Lourenço, P. Integrated Structural Safety Analysis of San Francisco Master Gate in the Fortress of Almeida. Int. J. Arch. Heri. 2018, 12, 761-778. [CrossRef]

37. Lerma, C.; Barreira, E.; Almeida, R.M. A Discussion Concerning Active Infrared Thermography in the Evaluation of Buildings Air Infiltration. Energy Build. 2018, 168, 56-66. [CrossRef]

38. Lerma, C.; Mas, A.; Gil, E.; Vercher, J.; Peñalver, M.J. Pathology of Building Materials in Historic Buildings. Relationship Between Laboratory Testing and Infrared Thermography. Mater. Construcción 2013, 64. [CrossRef]

39. Petrickova, M.; Joja, M. Interpretation of Traditional Structural Principles in Contemporary Architecture; Ostrava Technical University: Ostrava, Czech Republic, 2016; ISBN 978-80-248-3940-0.

40. Juan, F. Valor Barroco en la Arquitectura; General de Ediciones de Arquitectura: Valencia, Spain, 2006; ISBN 9788493516338. 
41. Domingo, A. La Crisis Del Siglo XVII: La Población, la Economía, la Sociedad; Espasa Calpe: Madrid, Spain, 1996; ISBN 978-84-2394994-6.

42. Bérchez, J. Arquitectura Barroca Valenciana; Bancaja: Valencia, Spain, 1993; ISBN 978-84-87684-38-8.

43. Loseby, S.T. Reflections on Urban Space: Streets through Time. Reti Medievali Rivista 2011, 3. Available online: https://core.ac.uk/ download/pdf/141654837.pdf (accessed on 16 November 2020).

44. Pace, S. History of urbanism in Spain, vol. 2, Centuries XVI, XVII and XVIII. Plan. Perspect. 2014, 29, 133-134. [CrossRef]

45. Torner, M.E. Sistemas de Análisis Mediante la Aplicación de Nuevas Herramientas al Estudio Morfológico Constructivo de la Iglesia de Nuestra Señora de la Asunción. Ph.D. Thesis, Universidad Cardenal Herrera-CEU, Valencia, Spain, 2015. Available online: http:/ / dspace.ceu.es/handle/10637/7387 (accessed on 16 November 2020).

46. Perfect-Prime. Temperature and Humidity Logger. User Manual. 2020. Available online: https://cdn.shopify.com/s/files/ 1/1291/1589/files/TH0165_new_manual_7a5fca2d-a739-4042-bcb2-6a870b8cc93c.pdf?13679988968750926951 (accessed on 16 November 2020).

47. EN-15758. Conservation of Cultural Property. Procedures and Instruments for Measuring Temperatures of the Air and Surfaces of Objects. 2010. Available online: https:/ / www.une.org/encuentra-tu-norma/busca-tu-norma/norma?c=N0046751 (accessed on 16 November 2020).

48. Fernández-Navajas, A.; Merello, P.; Beltrán, P.; Diego, F.-J.G. Software for Storage and Management of Microclimatic Data for Preventive Conservation of Cultural Heritage. Sensors 2013, 13, 2700-2718. [CrossRef] [PubMed]

49. Kurganov, V.A. Heat Transfer Coeficient. A-to-Z Guide to Thermodynamics, Heat and Mass Transfer and Fluids Engineering. Available online: http:/ / thermopedia.com/content/840/ (accessed on 16 November 2020).

50. Perilli, S.; Sfarra, S.; Ambrosini, D.; Paoletti, D.; Mai, S.; Scozzafava, M.; Yao, Y. Combined Experimental and Computational Approach for Defect Detection in Precious Walls Built in Indoor Environments. Int. J. Therm. Sci. 2018, 129, 29-46. [CrossRef]

51. Sfarra, S.; Yao, Y.; Zhang, H.; Perilli, S.; Scozzafava, M.; Avdelidis, N.P.; Maldague, X.P.V. Precious Walls Built in Indoor Environments Inspected Numerically and Experimentally within Long-Wave Infrared (LWIR) and Radio Regions. J. Therm. Anal. Calorim. 2019, 137, 1083-1111. [CrossRef]

52. FLIR Data Sheet. Building Applications of FLIR EXX-Series. Available online: https://www.flir-direct.com/pdfs / cache/www. flir-direct.com/e95/datasheet/e95-datasheet.pdf (accessed on 16 November 2020).

53. Liñán, C.R.; Morales-Conde, M.; De Hita, P.R.; Pérez-Gálvez, F. Inspección mediante técnicas no destructivas de un edificio histórico: Oratorio San Felipe Neri (Cádiz). Inf. Construcción 2011, 63, 13-22. [CrossRef]

54. Cañas, I. Thermal-Physical Aspects of Materials Used for the Construction or Rural Buildings in Soria (Spain). Constr. Build. Mater. 2005, 19, 197-211.

55. State Meteorological Agency of Spain AEMET. Available online: http://www.aemet.es/en/ (accessed on 16 November 2020). 